\title{
THE CONJUCTION OF TAX AUDITING MECHANISM WITH BEHAVIORAL AND INSTITUTIONAL PARAMETERS OF TAX EVASION: THE ROLE OF ACCOUNTING RULES AND FORENSIC ACCOUNTING
}

\author{
Dimitris Balios, Stefanos Tantos, Nikolaos Eriotis, Dimitrios Vasiliou \\ National and Kapodistrian University of Athens, Department of Economics, \\ Griparion Megaron, Sofokleous 1 and Aristeidou, 5th floor, Athens, Zip Code 105-59, \\ Greece \\ E-mail: dbalios@econ.uoa.gr, stantos@econ.uoa.gr, neriot@econ.uoa.gr, \\ dvasiliou@econ.uoa.gr
}

\begin{abstract}
This review study attempts to highlight the impact of various noneconomic, mainly behavioural and institutional factors on the level of tax evasion specifying the significance of the accounting rules and the contribution of forensic accounting to the detection and the prevention of financial statements. This analysis takes into account tax auditing parameters in order to determine whether and to what extent they affect taxpayer's behaviour to tax evade or not. Some useful conclusions are drawn regarding the determining factors of tax evasion pay attention to the role of accounting rules to the manipulation of financial statements. The contribution of forensic accounting against tax fraud emerges increasingly. The considerable increase in the cases of financial and tax fraud due to the weaknesses of the statutory audit to detect fraudulent activities impose the need for forensic accountants to deal with financial accounting and tax rules infringements. These conclusions may be essential and useful for tax policymakers to adopt restrictive measures against tax evasion.
\end{abstract}

KEYWORDS: auditing mechanism, tax evasion, accounting rules, forensic accounting

\section{INTRODUCTION}

Great research interest has emerged last decades as it concerns tax evasion, which expresses the attitude of taxpayers not to pay voluntarily and timely their tax liability imposed by the tax laws for a given tax year (IRS, 2007). Rational economic agents, who want to maximise their utility, decide to tax evade or not subject to some constraints, determining factors. They conceal their actual income entirely or underreport a share of it by comparing the expected gross benefits with the expected gross costs of not reporting income (Feige and Cebula, 2011).

Tax fraud in an underground economy has influenced significantly fiscal balance as well as growth prospects in many economies. Empirical studies claim that governments attempt to reduce the shadow economy which outcomes to tax evasion by implementing tax fraud combating policies. This policy-making seems to contribute significantly to the legal (official) economy's performance. Schneider, Raczkowski and Mroz (2015) assessing the size of the shadow economy of 28 European countries ascertain that it has reduced significantly. Characteristically, the average size of the shadow economy in 28 EU countries was $22.6 \%$ to GDP in 2003, which it declined to $18.6 \%$ to GDP in 2014 . 
Print ISSN: 2053-4086(Print), Online ISSN: 2053-4094(Online)

However, Buehn and Schneider (2016) have indicated that even though the size of tax evasion declines over the period 1999-2009, it shows a slight increase for the period 1999-2010 for most of the 38 OECD countries. They estimate that the average size of tax evasion across all 38 countries is $3.2 \%$ of GDP over the period 1999 to 2010.

During last years there is a debate about the fiscal consolidation programs in European Union (EU) and its implications to the social welfare of the EU people taking into account tax evasion and underground economy in general. Pappa, Sajedi and Vella (2015) taking into consideration a New Keynesian DSGE model with involuntary unemployment, an informal sector and public corruption, assess how the fiscal consolidation plans in Greece, Italy, Portugal and Spain influence tax evasion, output, unemployment and welfare. They find that during the consolidation programs tax evasion has increased and social welfare has been deteriorated. According to the empirical results, the expenditure cuts ${ }^{1}$ in conjunction with tax rate increases ${ }^{2}$, as the main instruments to fiscal consolidation, result in tax evasion rising and social welfare losses, especially in Greece and Portugal.

Tax evasion has critical fiscal implications since the government cannot collect the appropriate tax revenues in order to finance its public goods and services, according to the State fiscal budget. As a result, fiscal deficit arises increasing public debt. After that, tax burden rises in order to service public debt. This fact results in tax distortions and to unfair tax systems and significant social inequities. The honest taxpayers who cannot underreport their actual income pay more taxes than those who can tax evade (dishonest evaders) concealing a share of their income. In light of these adverse outcomes, researchers attempt to determine determinants and to estimate their impact on tax evasion in order to recommend policies which increase tax compliance and subsequently improve fiscal balance in a social welfare cost minimisation framework.

This review study attempts to analyse the impact of various non-economic, mainly behavioural and institutional factors on the level of tax evasion. More specifically, this analysis takes into account tax auditing parameters in order to determine whether and to what extent they affect taxpayer's behaviour to tax evade or not. Specific analysis is provided to the role of accounting rules to the manipulation of financial statements. Also, we refer to the contribution of forensic accounting against financial and tax fraud.

The rest of the paper is organized as follows. Section 2 provides a literature review on tax evasion and its major behavioural and institutional determining factors. Section 3 analyses the influence of accounting rule manipulation to the distortion of financial statements. Section 4 discusses the role of a forensic accountant to the combat against financial and tax fraud. Section 5involves an extensive discussion providing policy implications and laying out directions for further work. 
Print ISSN: 2053-4086(Print), Online ISSN: 2053-4094(Online)

\section{LITERATURE REVIEW}

\section{Economic, political and institutional parameters}

The theoretical framework of the literature in tax evasion indicates that the estimation of taxpayers' sensitivity to the deterrent parameters of taxevasion (audit rate, penalty rate) depends on the involved tax evasion theory (Dhami and Al-Nowaihi, 2010). Thetaxpayers when deciding to tax evade or not, exhibit behaviour described by the Prospect Theory. However, when taxpayers express their preferences, for instance, over private and public provision taking into account surveys, referenda, elections etc., then a standard utility function indicates these preferences in an expected utility theory framework. Dhami and Al-Nowaihi (2010) claim that, under the prospect theory, taxpayers are more sensitive in the probability of auditing and to be penalized. The individuals overweight the case to be punished and the deterrent effect to tax evade is much stronger than under the expected utility theory.

More specifically, according to the relevant literature in tax evasion, the taxpayer is described as a risk-averse agent who attempts to maximise his utility. His tendency to conceal fully or partly his income depends on the probability of detection and to be fined. These modelling approaches belong to the classical models of evasion (Allingham and Sandmo, 1972) or the "neo-classical school" (Christie and Holzner, 2006).

The so-called "tax morale school" comes to reject to classical modelling approaches of (Allingham and Sandmo, 1972). It is based on the behaviour of taxpayers and its determinants. Earlier studies (Andreoni, Erard and Feinstein, 1998; Christie and Holzner, 2006) assert that the attitude of a taxpayer to evade or not depends on three principal moral and social factors. More specifically, as higher are the moral values, the perception about the fairness of the tax system and the satisfaction concerning the provision of public goods and services, the less is tax evasion.

The "unreported economy" is ascertained to be considerably fluctuated due to variations in many factors such as tax rates, the public's dissatisfaction with government, and audit rates (Cebula et al.,1998;Feige and Cebula, 2011). Many prior research studies (Andreoni, Erard, \& Feinstein, 1998; Cuccia, 1994; Jackson \&Milliron, 1986; Kinsey, 1986; Long \& Swingen, 1991; Richardson \& Sawyer, 2001) have focused on tax evasion in most developed countries. Even though a lot of studies (Andreoni et al.,1998; Tan and Sawyer, 2003) have pointed out that comparative crosscountry analysis of tax evasion results to useful policy-making conclusions, research on a country-country basis is noticed to be low without answering the crucial question "Why the frequency of tax evasion varies among countries?". Jackson and Milliron (1986) attempt to answer to this issue. Jackson and Milliron (1986) provide the first significant literature review in tax evasion determining some critical demographic, economic and behavioural determining factors of tax evasion. More specifically, their analysis involves the following determinants: age, gender, education and occupation status which are considered to be demographic factors; income level, income source, marginal tax rates, sanctions and probability of detection which are considered to be 
economic factors; complexity, fairness, revenue authority initiated contact, compliant peers and ethics or tax morale which are considered to be behavioural factors.

Riahi-Belkaoiu (2004), based on data from 30 countries, investigates the relationship between determining factors and tax evasion. He claims that the higher the level of economic freedom, the level of importance of the equity market, the effectiveness of competition laws and higher moral norms, the lower is the size of tax evasion across countries. Richardson (2006) expands the work of Jackson and Milliron (1986) and Riahi-Belkaoiu (2004) investigating key demographic, economic and behavioural determining factors of tax evasion attempting to fill a significant gap in the relevant tax literature. Richardson (2006) based on data for 45 countries, assesses, on a crosscountry basis, many of determining factors of tax evasion as it was defined by Jackson and Milliron (1986) in order to understand tax evasion across countries. Richardson (2006) takes into consideration in the empirical analysis ten of the variables involved in Jackson and Milliron's (1986) study. He assesses the impact of age, gender, education, income level, income source, marginal tax rates, fairness, complexity, revenue authority initiated contact and tax morale in the size of tax evasion. He points out that the non-economic determining factors influence more the tax evasion than the economic ones. More specifically, we cite the findings of the relevant literature as it concerns various (demographic, economic, behavioural, tax system) determinants of tax evasion.

The role of economic policy is considered to be crucial in the reduction of tax evasion. However, the implementation of economic policy is almost always confronted with the question of its interaction with the political system and institutions. Economic decisions are taken by members of a government and involve political costs or benefits. The political cost of a financial decision can lead to its cancellation, even if purely economic terms are the best decision. However, it is not just the political system that has an impact on economic decisions. Equally important is the institutional framework within which the government carries out its policy. Tax policy can not be an exception to the inherent tendency of policy and institutions to influence economic decisions. Therefore, tax policy decisions cannot be fully explained if one only examines their purely economic determinants. Interest groups also play a role. Many of them have a bargaining power that exceeds their numerical power in votes and so they are able to cancel the planned tax policies. The same applies to the institutions. They are a crucial component in the decision-making process, as they set the framework within which the choices of economic policy-makers are available.

Why do some countries have high tax evasion, while others have efficient tax systems with high tax effort rates? Why do some countries manage to reduce tax evasion while others can not?

These are vital questions whose response requires a political and institutional approach alongside the economic one. Political models for tax evasion use policy and institutional variables to explain issues that could be interpreted by purely economic factors if we had assumed an economy without conflicts of interest. However, economic equilibrium models do not lose their usefulness. They can be used as benchmarks since they refer 
to optimal results, i.e. "how should things be". Thus one can measure the gap between the results of optimal tax policy (in case of implementation) and the corresponding actual loss of welfare.

As we have already mentioned, according to the tax morale school, the attitude of taxpayers to evade or not depends on the moral values, the perception about the fairness of the tax system and the satisfaction with respect to the provision of public goods and services, the less is tax evasion.The perception of taxpayers about the democratic procedures adopted in the tax policy making is an important determining factor of tax evasion across countries (Alm, McClelland, \& Schulze, 1999; Pommerehne \& WeckHannemann, 1996). Taxpayers consider that the political system become more transparent enhancing its reliability and discouraging their attitude to tax evade (Feld \&Tyran, 2002; Torgler, 2003b; Torgler, Schaltegger \& Schaffner, 2003). Earlier studies have also indicated that the perception of citizens to finance the public expenditures, through taxation, in order to receive government goods contribute significantly to reduction of their behaviour to tax evade (Becker, Buchner and Sleeking, 1987; Alm, Jackson and McKee, 1992; Alm, McClelland and Schulze, 1992; Alm, Sanchez and DeJuan, 1995). Their findings point out that free riding to finance public goods is weak.

Studies (Feige, 1994; Feige and Cebula, 2011) claim that as higher is the degree of dissatisfaction $^{3}$ with a government with respect mainly to the provision of public goods and services, the higher is the willingness of taxpayers to tax evade. Pommerehne and Weck-Hannemann (1996) consider that the attitude of individuals towards to tax evade depends on the degree of publicness of public goods, on the perception of taxpayers whether the provided public goods satisfy their individual preferences and on the deviation of policy-making from individuals' demands for public goods. Pommerehne and Weck-Hannemann (1996) also assert that the tendency to tax evasion depends on the institutional arrangements of collective decision-making. For instance, they find that in cantons of Switzerland with direct democracies, where there is strong direct control of policymaking by the citizens (through obligatory and optional referenda) the share of concealed income to the actual one is much lower than the Cantons with representative democracies. Citizens have much weaker control of the government policy-making, which may result in deviation from individuals' demand for public goods. Pommerehne and Weck-Hannemann (1996) assert that tax evasion decreases in case that the taxpayers have direct control over government budget. After that, they argue that the fight against tax evasion should not be based on penalty system and the auditing mechanism but on strengthening the democratic institutions providing more delegation of policymaking decisions to the citizens/voters. Hug and Spörri (2011) is another study which supports the view that institutions play major role in the taxpayer's attitude to evade. Hug and Spörri (2011) assess how institutions influence tax morale based on different sets of referendum across countries. They find that the institutions allowing for direct involvement of policy issues (for instance taxation issues) through referendums enhance the link between trust and tax morale. This link is strongest in transition countries where theinfluence of referendum institutions is significant of the trust in parliament and in the political system in general. The relation between tax morale and trust in the political system is another crucial issue which has discussed in the literature. Studies (e.g. Torgler, 2006; Schneider, 2002) indicate that this link is 
stronger especially in post-commnunist countries where the level of trust is too low. Therefore, even though these countries implement plenty of democratising reforms tax morale is the low indicating tendency towards tax evasion. They also point out that there are differences in the impact of various referendum institutions on the level of tax morale across countries. They indicate that in countries with sufficiently high levels of trust, tax morale may increase carrying out referendums. Instead, in countries with low levels of trust, tax morale may decrease.

The taxpayers' perception of fairness is found out to influence tax evasion (Jackson \& Milliron, 1986; Richardson \& Sawyer, 2001) significantly. Studies (Richardson 2006; Spicer 1974; Song and Yarbrough, 1978; Hite and Roberts, 1992) indicate that tax evasion is negatively related to the perception of taxpayers about the fairness of the tax system. Tax evasion also reduces when the perception of tax fairness prevails. Taxpayers may accept to declare their actual income if they feel that part of their paid taxes finances public goods and services (Christie and Holzner, 2006). Most taxpayers usually accept to be taxed in order specific categories of citizens to be granted (e.g. the disabled, the elderly, those with dependent children, single mothers, etc.).

Moreover, the fairness of the tax system may be strengthened by the fact that tax systems are usually complex with various tax rates depending on the income level. This incorporates distributional effects facilitating to be acceptable by the standard taxpayer. In most Western economies, the income tax system contributes significantly to a potential social redistributing policymaking.Policymakers should focus on implementing measures which encourage taxpayers to pays taxes voluntarily enhancing the voluntary tax compliance instead on increasing deterring measures such as an increase of the number of audits and fine rates (Pickhardt \& Prinz, 2014). Policies involving, for instance, a simpler taxation system, more service-oriented tax authorities, may contribute to cooperative tax behaviour strengthening the trust to tax authorities.

\section{Corruption}

Corruption is one of the most important determinants of tax evasion. This is a concept for which there is no specific definition that is commonly accepted. This is because the concept of corruption has broad content, making it difficult to have a definition that includes all its forms. Often, even for the same form of corruption, there are conflicting definitions.According to Transparency International, corruption is defined as the abuse of power to gain personal benefit and hurts anyone dependent on the integrity of the person who has and abuses that power. It is classified into three major categories:

1. High Corruption: It is the corruption that takes place at the government level or high-level government officials in order to gain benefits from rulers at the expense of the public interest.

2. Low-level corruption (Petty Corruption): It is the corruption that occurs daily by middle and low-level government officials in their dealings with citizens. The transaction may concern access to services or goods (hospitals, schools, town planning, police departments and other public services).

3. Political Corruption: It is the formulation of the policy content, the institutions and the rules as it concern the allocation of resources and the financing of the economy 
by political decision-makers, in order to keep them in power and to obtain economic benefits as the expense of the society.

Hodgson and Jiang (2007) focus on the institutional dimension of corruption. They argue that the precondition of corruption is not the involvement of a state official. Their position is documented in the fact that corruption is, among other things, a moral issue and, as such, does not necessarily fall within the scope of the public sector. Corruption is an element of all the institutions of society and therefore, cannot be confined to the public sector alone. This approach describes corruption as organisational corruption. Having defined the institutions as a system of social norms that structures social interactions, Hodgson and Jiang (2007) define as organisational corruption the corruption that is developed in enterprises and states, which are more specific forms of institutions. In this context, they strongly criticise the neoclassical-utilitarian approach of corruption, considering that it restricts the study of corruption in the public sector and does not take into account its ethical and institutional determinants.

Pellegrini (2011) seems to agree with Hodgson and Jiang (2007). He notes that a definition of corruption that confines it to the private sector leads to the simple and unrealistic conclusion that the reduction of the public sector is sufficient treaty to combat corruption. In the same context, he also criticises the "partitioning" of the concept of corruption into "corruption in the public sector" and "market failure in the private sector". According to the partition approach, public sector failures are characterised as corruption, while private sector failures are not corruption but failures of the market mechanism. With this partition, according to Pellegrini (2011), the state appears to be the only source of corruption, while the private sector is free of charge.

Research in tax evasion has also argued that as the level of direct contact with tax administration officials reduces the tax evasion also declines (Spicer and Lundstedt's, 1976; Wallschutzky, 1984; Klepper and Nagin, 1989a, 1989b; Brooks and Doob, 1990; Tanzi, 2000; Sarker, 2003; Torgler \& Murphy, 2004). In other words, tax evasion is ascertained to be negatively related to revenue authority to enforce restrictive measures. However, other studies (Strumpel, 1969; Jackson \& Milliron, 1986) find that even though some countries, especially southern European countries, appear a long period of tax compliance measures, the relative compliance rates are the lowest in Europe. Sanyal, Gang and Goswami (2000) also focus on investigating the issue of corrupted tax collection mechanisms. They present a model, according to which, when tax administration is corrupted, then tax collection may result in a loss of tax revenue. This entails a "Laffer curve" type behaviour. They demonstrate with their study that high tax rates do not characterise the efficiency of the tax system. Instead, an uncorrupted taxcollection mechanism is needed to combat tax evasion and increase the tax effort. Alm, Martinez-Vazquez, and McClellan (2016) attempt to investigate the relationship between corruption and tax evasion based on a theoretical model that incorporates the potential for bribery in a firm's tax reporting decisions. Their findings indicate that the corruption of tax official, through bribes, strengthens tax evasion. More specifically, they point out that sales reported for taxes reduce by $4 \%-10 \%$ in case that tax inspector' bribes occur. Cerqueti \& Coppier (2011) examine the relationship between tax rates and tax collection, which depends on the level of corruption of tax authorities. They 
take into account in their analysis a Ramsey model of economic growth where public goods are financed by taxation. However, taxes may be evaded due to corrupted tax inspectors. Cerqueti \& Coppier (2011) separate countries in three categories depending on the level of corruption: "low, middle and high shame" countries. They indicate that for all countries there is a positive relation between growth rate and tax rate up to a threshold value. After this threshold, growth rate decelerates as the tax rate continues to rise up. They also find that growth rate is more sensitive to changes on tax rates in countries with less corrupted tax inspectors, where the "shame effect" 4 does not make sense.

The corruption index, as well as the quality of the judicial system, plays a major role in the perception of about fairness of the tax system (Christie and Holzner, 2006). Introducing a corruption variable in their analysis, proxied by the Transparency International Corruption Perception Index, they indicate that either corruption or quality of the judicial system influences tax evasion significantly for value-added taxation, personal income tax taxation and excise taxation. More specifically, they find that the higher the level of corruption and/or poorer the judicial (legal) and administrative system, the higher is also tax evasion. High corruption index (the higher the index, the lower the level of corruption) indicates that in case of detection of tax evasion, the authorities will fully sanction penalties to the uncovering concealed income. Instead, in a corruptive auditing environment, a taxpayer is more often to bribe auditor rather than accept to pay the fines of the conceal income.

Corruption norms are also considered to be significant for tax evasion in a country even in cases that other countries convey corruption. More specifically, De Backer, Heim \& Tran (2015) examine how cultural norms and enforcement policies affect illicit corporate activities in the U.S. based on confidential Internal Revenue Service (IRS) audit data. They ascertain that the owners of corporations who come from highly corrupted countries tax evade more than other owners and this effect is strongest for small corporations or privately owned. This evidence is in accordance with Fisman and Miguel (2007) study of corruption norms influence on individual behaviour. They also point out that the influence of corruption norms on tax evasion declines as the firm's size increases. This evidence highlights the fact that the attitude of owners in favour of tax evasion is differentiated from that of managers' preferences to tax evade. Managers' attitude to tax evasion is not weighted with firm' size (Joulfaian, 2000).

\section{Tax morale}

Tax morale, which expresses the moral principles or values of taxpayers to service their tax obligations, is another important determining factor of tax evasion (Torgler \& Murphy, 2004; Alm, Martinez-Vazquez, and Torgler, 2006). Earlier as well as recent studies (Richardson, 2006; Spicer, 1974; Spicer and Lundstedt, 1976; Torgler, 2003a; Riahi-Belkaoiu, 2004) claim that tax evasion is affected adversely by deterioration in the tax morale of taxpayers. However, tax morale is not uniquely connected with the moral values of taxpayers but it is also related to more democracy, more local government and more direct democracy (Torgler, 2003a). Alm, Kirchler and Muehlbacher (2012) argue that both economic and psychological factor may enhance tax compliance inducing mutual trust and cooperation between citizens and authorities 
(elected government officials and tax authorities). Dell'Anno (2009) adopting in his analysis a dynamic model of aggregate tax evasion for Latin American countries ascertain that the size of tax evasion depends on tax morale. Tax morale also depends on the taxpayers' attitude to honesty and social stigma (the relationship between taxpayers and the government; Torgler, 2001). He also asserts that this attitude of taxpayers is influenced by their perception about the size of tax evasion and the government's effectiveness in ensuring the public interest. Taxpayers usually reconsider their perception about the government according to their satisfaction level with the implemented policy making, collective decision-making, (Schnellenbach, 2006).

\section{Fines and controls}

Apart from the political and institutional factors in the broad sense, we also distinguish the third group of factors, linked to corruption, and co-modulate the level of tax evasion. Becker (1968), studying tax evasion and optimal methods of dealing with it, distinguished two tools for its elimination, fines and controls. The more audits are implemented, the higher the likelihood of detecting tax evasion. Likewise, imposing a fine on those arrested for tax evasion is a powerful disincentive for committing such offenses.

As Allingham and Sandmo (1972) note, the two tools are complementary, in the sense that the reduction to one can be offset by an increase to the other. However, the cost of using the two tools varies substantially. Increasing the likelihood of detection requires more audits, hence increasing public spending, in order to recruit additional staff or to overtime the existing ones in order to carry out the additional audits. Raise of government spending is also required in order the appropriate logistical infrastructure to be developed. On the other hand, the increase in the fine has zero costs.According to Myles (1995), the adoption of the fine as a policy tool to combat tax evasion has two important constraints. The first is that it may not be in the complete authority of the government, as the amount of the fine is often determined by court decisions, which also take into account non-economic factors, such as the level of fines for other offenses. The second constraint is that if tax evasion is widespread among taxpayers, there may be strong reactions to any attempt to reduce it.

The literature in tax evasion has indicated that the attitude of a risk-averse taxpayer to evade concealing a share of his income depends on the probability of detection and the penalty tax rate (in case of detection) (Cowell, 1990; Pommerehne and WeckHannemann, 1996). The expected gross cost of concealing income to the tax administration is increasingly related to the expected risk/cost to be audited (Pestieau, Possen, and Slutsky, 1994; Erard and Feinstein, 1994; Caballe and Panades, 1997). Feige and Cebula (2011) define this probability of audit as the percentage of filed federal income tax returns that are audited by tax administration government officials. More specifically,Zaklan, Westerhoff \& Stauffer (2008) support the view that increase of probability of audit as well penalty rates result in lower tax evasion. Andrei, Comer and Koehler (2014) following the agent-based models of tax evasion of earlier studies (Korobow, Johnson and Axtell, 2007; Hokamp and Pickhardt, 2010) models indicate that in network structures with higher levels of centrality across the agents the level of 
tax evasion reduces especially by expecting tremendous punishment in proportion to their incomes. Gupta (2008) ${ }^{5}$ also shows that higher the penalty rates the lower is the tendency of a taxpayer to conceal income.

Furthermore, he nominates that a reduction of tax evasion, due to higher fine rates or lower corruption behaviours, causes the government to inflate the economy at a higher rate $^{6}$. Hokamp and Pickhardt (2010) investigate the extent of income tax evasion in an agent-based model with heterogeneous agents. These agents express different behavioural types, different individual risk-preferences and different taxable incomes. Their findings, being following earlier empirical evidence (e.g. Allingham and Sandmo 1972; Alm et al., 1992; Bloomquist, 2006; Zaklan et al. 2009, 2008), indicate that the higher the probability rate of audit, the lower is the tendency to tax evasion. Snow and Warren (2005) argue that the taxpayers' uncertainty to be detected or not in case of concealing taxable income discourages them from tax-evading.

Pommerehne and Weck-Hannemann (1996) also find empirically that the probability of audit and detection and penalty tax rate have the expected negative sign to the tax evasion model. However, they ascertain that none of them is statistically significant. Previous studies mainly focused on the U.S. economy, support this view (Witte and Woodbury, 1985; Graetz and Wilde, 1985; Beron, Tauchen and Witte, 1988; Elffers, 1991; Cebula, 2001; Feige and Cebula, 2011) have indicated that the influence of the audit rate of tax administration on tax evasion is not significant in order to discourage taxpayers from tax-evading. Instead, researchers (Feige and Cebula, 2011; Musgrave, 1987; Cebula, Coombs, and Yang, 2009; Slemrod, 1992) ascertain that specified tax reforms oriented in tax-evasion disincentives, such as Tax Reform Act of 1986 in the U.S. ${ }^{7}$, may weaken the tendency of taxpayers to evade.

The classic model of Allingham and Sandmo (1972) presents the taxpayer as a riskaverse and rationally expected utility maximiser who decides his concealed income to order to maximise his expected utility subject to the constraint to be detected. In case of detection, he knows that he has to pay a penalty rate of tax on the concealed amount of income. Therefore, assuming that the taxpayer is risk-averse and his expected utility must be increasing and concave, then an increase of the probability of audit and detection decreases his attitude to tax evade. Furthermore, tax evasion behaviour declines as the penalty rate increases. The share of the concealed income to the gross income of the taxpayer also rises as his absolute risk aversion decreases. Yitzhaki (1974) modifies the original classic model Allingham and Sandmo (1972). This study considers that the penalty is imposed not on the evaded (concealed) income but on the amount of evaded. He finds that higher tax rates exacerbate tax evasion.

However, other studies (Andreoni, Erard and Feinstein, 1998; Sandmo, 2005) claim that both Allingham-Sandmo and Yitzhaki models estimate much higher tax evasion than what is observed. The actual audit rate may diverge by the theoretical (subjective) probability of audit of the taxpayers who over-estimate the probability of an audit (Sandmo, 2005). Sandmo asserts that penalty rate becomes less effective in tax evasion when taxpayers' social and moral considerations are incorporated in the analysis. A recent study of Hashimzade, Myles \& Tran-Nam (2013) supports the view that the 
Yitzhaki version of the Allingham-Sandmo model of the individual tax compliance results to two incorrect predictions. Firstly, the empirically observed level of tax evasion is over-predicted. Secondly, this model shows that tax evasion reduction when tax rate increases due to the assumption that the punishment to be detected for evasion is proportional to tax evaded. These drawbacks have resulted to a significant number of studies which focus on behavioural economics in order to determine the taxpayers' compliance. Hashimzade, Myles \& Tran-Nam (2013) consider that the relative behavioral economics literature is separated into two groups. The first one is based on non-expected utility theory which broadens the range for the structure of preferences and it indicates that the individual taxpayers' choices to tax evade are not based on knowledge of objective probabilities of auditing and detection. The second group includes studies which assess social interaction (e.g. psychic costs, social customs and social norms and tax morale) between taxpayers within a social environment which influences their attitude to tax evade.

\section{The role of technology}

Earlier studies have also indicated that the use of technology and appropriate tax information systems (third-party reporting, cross-checking, or better auditing algorithms) in auditing and detecting tax evaders can contribute significantly to the alleviation of the tax evasion problem. Balios and Tantos (2019) assert that tax auditing information system could be a tool against tax evasion, a tool for an economy to grow, especially in countries that face fluctuations in economic activity. They claim that a fair and efficient tax auditing information system increases the reliability of tax administration, improves taxpayers' tax compliance and causes a developmental trajectory for the economy.

Studies uses microdata to shed light on enforcement technologies such as third-party reporting (Slemrod, Blumenthal, and Christian, 2001; Saez, 2010; Kleven et al. 2011; Chetty, Friedman, and Saez 2013; Naritomi, 2015, Balios, 2020), paper trails (Kumler, Verhoogen, and Frias, 2015; Pomeranz, 2015), crosschecking (Carrillo, Pomeranz, and Singhal, 2014), targeted auditing strategies (Aparicio, 2012; Almunia and LopezRodriguez, 2014) and third-party monitoring of customs duty collection (Yang, 2008a, 2008b). Alqtish, Alqirem \& Kasem (2018) attempt to determine the impact of electronic tax audits, carried out by auditors of the income in the sales tax department in Jordan, on tax evasion. They mention that Jordan appears significant-high tax evasion by either underreporting income or inflating deductions. They point out that electronic tax audits, accompanied by computer techniques development of computer skills of tax auditors, contribute significantly in reducing tax evasion.

Casaburi and Troiano (2016), being followingthe aforementioned Myles (1995) argument, assert that political incentives play a significant role in the adoption of these monitoring technologies especially in cases that policymakers feel that they will lose the voter's support. Then, policymakers may delay the implementation of tax enforcement measures. Casaburi and Troiano (2016) assess the taxpayers' attitude to tax evade after the implementation of the Ghost Buildings Program anti-tax evasion policy in Italy, which is considered as a country with poor tax culture. This program uses innovative monitoring technologies in order to trace out any concealed undeclared 
to taxation real estate property, especially buildings. The program provides monetary as well as the non-monetary benefit for the taxpayers who decide not to evade. Casaburi and Troiano (2016) find that there is a negative association between the technological audit of tax evasion and political incentives. More specifically, they show that an increase of $1 \%$ in deviating from the town-level program, results in an increase of the re-election probability of the local officials by $4.8 \%$. Furthermore, tax culture against tax evasion is another critical parameter which affects the political incentives of policymakers to implement anti-evasion policies.

Floropoulos et al. (2010) assess the success of the Greek Tax Information System by integrating constructs from DeLone and McLean (2003) and Seddon's (1997) Information System (IS) success models. This is attained by studying the taxation agencies employees' degree of satisfaction from using the system. They ascertain that Greek Tax Information System can be more successful through higher service quality (e.g. higher quality of taxation processes, more simplified and standardised taxation services, improved decision-taking processes), and higher information quality (e.g. provision of more comprehensive, accurate and reliable information) without overlooking the system quality effect.

\section{Accounting rules manipulation}

A less "strict" institutional framework as it concerns accounting rules may provide significant flexibility to accountants in order to manipulate financial statements in accordance with the firms' interest appearing lower earnings than the actual ones. This fact may result to lower taxable income of firms. Casabona and Gornik-Tomaszewski (2007) discuss this issue by emphasising on the accounting information derived by financial statements which are diversified based on changes on the accounting rules. More specifically, they assert that even though the traditional accounting model based on historical cost accounting is considered to be reliable, easy to verify and to understand for the recognition and the estimation of identifiable tangible assets. However, Casabona and Gornik-Tomaszewski (2007) claim the adoption of historical cost counting for intangible assets intellectual capital, human resources, brand names, technology advances or corporate culture) may result to under-valuing and underrecording assets.

Furthermore, they indicate that other intangible assets, such as brand assets, assets arising from marketing and supplier relationships, and knowledge assets developed from research and development, are not recorded at all. This fact may result in great differences between companies' book value and market values emerging the fair-value accounting rule. Thereafter, the Financial Accounting Standards Board (FASB) and the International Accounting Standards Board (IASB) encourage the adoption of a mixed accounting model based primarily on historical cost and on the rising application of fair value accounting rule. This combination of accounting rule may result to financial statements with higher accuracy to the actual economic performance and subsequently to more reliable taxable income.

However, fair value accounting rule appears drawbacks provoking distortions in the balance sheet and income statements. More specifically, unrealised changes in fair value 
may results in operation statement distortions presenting false gains and losses in financial statements and providing subsequently unrealistic taxable income. Thereafter, Casabona and Gornik-Tomaszewski (2007) claim that proper matching of assets and liabilities in financial statements may be applied under the historical cost accounting rather than the fair value. The fair value accounting rule is considered to be more reliable in case of publicly observed markets (investment securities, financial instruments of banks and financial institutions).

Futhermore, accounting rules manipulation may be more effective in case that tax base is strongly affected by firm-specific determining factors. For instance, Balios et al. (2020a) indicate that that the effective corporate income tax rate is variously affected by firm-specific determining factors especially under unstable and non-flourishing economic periods. They point out that that the relation between effective corporate income tax rate and determining factors is less significant (sensitive) during the precrisis period in comparison with the respective empirical findings after the outburst of the economic crisis in European Union. Balios et al. (2020b) investigate the determinants of the effective corporate tax rate of companies of the European Union (EU) discriminating between northern and southern economies taking into consideration prior research that has indicated that there is a wide gap between northern and southern EU economies as it concerns in some cases both fiscal as well as structural divergences. They also assert that that the effective corporate income tax rate is variously affected by firm-specific determining factors for both northern and southern economies. Prior research evidence indicate that that the manipulation of financial statements and undeclaration of firm's earnings depends on the significance of firmspecific determining factors.

\section{The Role of the Forensic Accountant}

Prior research has also indicated the significance of the forensic accountant to the combat against manipulation of financial statements and tax fraud in general. The considerable increase in the cases of financial and tax fraud due to the weaknesses of the statutory audit to detect fraudulent activities impose the need for forensic accountants to deal with financial accounting and tax rules infringements (Eliezer et al., 2015). Creative accounting techniques are widely used by many companies in order to distort their actual economic performance. Thereafter, the need for the intervention of a forensic accountant is considered to be crucial to the detection of fraudulent activities indicating the manipulation of financial statements. Forensic accountants adopt many of the auditing mechanisms of tax officers to the investigation of non-disclosed income by focusing on specific income items undeclared in tax statements. Meldman et al. (2001) indicate some of the tax auditing techniques related to audit for cancelled or paid checks, real estate transaction documents, public records. Plenty of previous studies have discussed this issue. For instance, a recent study by Khersiat (2018) analyses the data from 125 forensic accountants working in Jordanian accounting and auditing firms. He points out that the role of the forensic accountant is very important against fraud in Jordan and that qualifications, expertise and analytical skills of a forensic accountant with a completely independent attitude ensures the detection of the manipulation of financial statements in companies. This manipulation may be applied in different forms, such as misinform on revenues, delay reporting on revenues, reduction of the values of 
assets, and manipulation of estimates of reserves. Alkubais (2016) also highlights the contribution of forensic accounting in Jordan. Another study by Akkeren et al. (2014) points out the need for the implementation of forensic accounting in Australia since it lacks regulatory provisions for accountants. Other studies have also concluded to the significance of the role of forensic accounting in other countries. AI Musalam et al. (2015) discuss the role of forensic accounting in detection of fraud in Bahrain.Enofe et al. (2015) assess the role of forensic accounting in curbing financial crimes focusing on the banking system of Nigeria. They claim that conventional accounting techniques cannot detect and prevent effectively financial crimes suggesting the adoption of the services of forensic accountants. Adebisi et al. (2016) have also supported the significant contribution of forensic accounting in the detection of fraud in Nigeria.Financial accountant evolvement in the combat against financial and tax fraud emerges increasingly so that relevant certifications, e.g. Certified in Financial Forensics (CFF), Certified Forensic Accountant (CRFAC), Accredited in Business Valuation $(\mathrm{ABV})$, Certified Fraud Examiner (CFE) have been developed in order to support and legitimise the forensic accounting service (Domino et al., 2017).

\section{DISCUSSION ISSUES AND POLICY IMPLICATIONS}

Taking into account the relevant literature on tax evasion and tax auditing mechanisms, we ascertain that there are several studies which deal with the empirical investigation of various determinants of tax evasion. Some surveys have also focused on the empirical estimation of tax evasion, but no strong micro-foundation has been developed in the context of a model linking behavioural and institutional determinants of tax evasion with tax auditing mechanism.

Some useful conclusions are drawn regarding the determinants of tax evasion and the role of tax auditing mechanisms and the extent to which they affect it per EU economy. The conclusions of relevant studies may be important and useful to tax policymakers in order to implement appropriate corrective tax auditing measures targeting to fiscal consolidation and the assurance, to the maximum possible extent, of social welfare.

Recognizing the importance of institutional factors, researchers should take them into consideration as principal determining variables. Among them, the factors that are related to the perception of taxpayers for the state are also significant. The relative literature (e.g. Feld \& Tyran, 2002; Torgler, 2003; Torgler, Schaltegger \& Schaffner, 2003) argues that the more convinced are taxpayers that the state is credible and transparent the more tax evasion reduces. In order to provide a complete picture of the tax evasion determinants, we also point out the relation between tax evasion and the tax system's efficiency as derived from the tax effort index.

Policy implications may be involved in the adoption of a stable, clear and long-run accounting rules institutional frameworks uninfluenced by government policies changes. This fact ensures controlled reliable financial statements which present the actual economic performance of firms resulting subsequently to reliable tax statements. 
Additionally, the rising rate of financial crimes and tax fraud emerge the need for the establishment of forensic accounting legislation framework. This may be accompanied by the adoption of policies which enhance the qualifications and skills of forensic account by providing specialized training and practices to conventional accounting auditors. The contribution of Universities and other training institutions seems to be crucial to this policy making (Khersiat, 2018).

To end with, by this review study, we consider that we are contributing to the development of a benchmark that can be the basis to the constant effort for greater stability and effectiveness in the way a society and economy operates. As a final point, some useful conclusions are drawn regarding the determining factors of tax evasion pay attention to the role of accounting rules to the manipulation of financial statements. The contribution of the forensic accounting against tax fraud emerges increasingly. The great increase in the cases of financial and tax fraud due to the weaknesses of the statutory audit to detect fraudulent activities impose the need for forensic accountants to deal with financial accounting and tax rules infringements. These conclusions may be important and useful for tax policy makers to adopt restrictive measures against tax evasion.

\section{Endnotes}

${ }^{1}$ Spending cuts fiscal program reallocates production towards the legal (formal) sector discouraging tax evasion.

${ }^{2}$ Tax rate increase resulting to additional tax burden induces agents to produce in the informal (shadow) sector.

${ }^{3}$ The degree of dissatisfaction includes: (a) the degree to which the taxpayersdistrust public officials to fulfil their job obligations; (b) the degree to which the taxpayers perceive government officials to be dishonest and corrupted; and (c) the degree to which the taxpayer consider that government officials waste public (money) expenditures financed by taxation.

${ }^{4}$ The specific "inner honesty" of the country.

${ }^{5}$ Gupta (2008) uses a simple overlapping generations framework in order to examine the relationship between tax evasion, determined endogenously, and financial repression (an obligatory "high" reserve deposit ratio requirement) for four Southern European countries (namely, Greece, Italy, Portugal and Spain).

${ }^{6}$ Instead, inflation rate diminishes when tax evasion declines due to a fall in the tax rate. He also finds that as the size of tax evasion rises, resulting from lower penalty rates and higher corruption, financial repression increases (rise in the reserve requirements) as well as money growth rate falls as part of a welfare maximizing behaviour of the government. However, he asserts that in case of tax evasion augmentation, due to lower tax rates, this fact tends to abate the optimal degree (the severity) of financial repression. The growth rate of money supply and the reserve requirement moves in the opposite direction.

${ }^{7}$ According to Ott and Vegari (2003), Tax Reform Act of 1986 resulted to major reductions in the personal income tax rate, it replaced the 14 bracket tax Schedule (ranging from 11 to 50 percent) with only two tax brackets (set at 15 and 28 percent). 
European Journal of Accounting, Auditing and Finance Research

Vol.8, No.2, pp.59-80, February 2020

Published by ECRTD-UK

Print ISSN: 2053-4086(Print), Online ISSN: 2053-4094(Online)

It broadened the tax base by reducing the eligible expenses (itemized deduction) that taxpayers can claim on federal income tax returns which subsequently decrease taxable income.

\section{References}

Adebisi, J. and Matthew, O. (2016) The Impact of Forensic Accounting in Fraud Detection and Prevention: Evidence from Nigerian Public Sector, International Journal of Business Marketing and Management, 1(5) 34-41.

AI Musalam, L. and Kukreja, G. (2015) The Role of Forensic Accounting in Fraud Investigations:A Survey Based Research from Kingdom of Bahrain, Journal of Business Management and Information Systems, 2(1) 168-184.

Akkeren, J. and Tarr, J. (2014) Regulation, Compliance and the Australian Forensic Accounting Profession, Journal of Forensic \& Investigative Accounting, 6(3) $1-26$.

Alkubaisi, A. (2016) An Empirical Investigation of the Forensic Accounting from Judicial and Forensic Accountant Point of View in Jordan, Jordan Journal of Business Administration, 12(1).

Allingham, M. and Sandmo, A. (1972) Income Tax Evasion: A Theoretical Analysis, Journal of Public Economics, 1(3-4) 323-338.

Alm, J., Jackson, B.R. and McKee, M. (1992) Estimating the Determinants of Taxpayer Compliance with Experimental Data, National Tax Journal, 45 107-114.

Alm, J., Kirchler, E. and Muehlbacher, S (2012) Combining Psychology and Economics in the Analysis of Compliance: From Enforcement to Cooperation, Economic Analysis and Policy, 42(2)133-152.

Alm, J., McClelland, G. and Schulze, W. (1992) Why do people pay taxes?, Journal of Public Economics, 48 21-38.

Alm, J., Sanchez, I. and DeJuan, A. (1995) Economic and Noneconomic Factors in Tax Compliance, Kyklos, 48(1) 1-18.

Alm, J., Martinez-Vazquez, J. and McClellan, C. (2016) Corruption and firm tax evasion, Journal of Economic Behavior \& Organization, 124 146-163.

Alm, J., Martinez-Vazquez, J. and Torgler, B. (2006) Russian Attitudes Toward Paying Taxes - Before, During, and After the Transition, International Journal of Social Economics, 33 832-857.

Alm, J., McClelland, G. and Schulze, W. (1999) Changing the Social Norm of Tax Compliance by Voting, Kyklos, 52(2) 141-171.

Alqtish, A., Alqirem, R. and Kasem, F. (2018) The Impact of Electronic Tax Auditing on the Reduction of Tax Evasion from the Perspective of the Income and Sales Tax Department in Jordan, Journal of Accounting, Finance \& Management Strategy, 13(1) 77-104.

Andrei, A., Comer, K. and Koehler, M. (2014), An agent-based model of network effects on tax compliance and evasion, Journal of Economic Psychology, 40 119133.

Andreoni J., B. Erard and Feinstein, J. (1998) Tax Compliance, Journal of Economic Literature, 36(2) 818-860. 
Aparicio, G. (2012) Monitoring and Its Interaction with Punishment in Tax Enforcement: Evidence from a Regression Discontinuity Design, Working Paper, Georgetown University.

Balios, D. (2020) The Impact of Big Data on Accounting and Auditing, International Journal of Corporate Finance and Accounting, 7(2), 1-10

Balios, D. and Tantos, S. (2019) The Characteristics of a Fair and Efficient Tax Auditing Information System as a Tool against Tax Evasion: A Theoretical Framework, International Journal of Economics and Management Engineering, 13 (6) 777-780.

Balios, D., Tantos, S., Eriotis, N. and Vasiliou, D. (2020a) Effective corporate income tax rates to the economies of the European Union in the light of the impact of the economic crisis in the Eurozone, International Journal of Economics and Business Administration, 6(1) 1-11.

Balios, D., Eriotis, N., Tantos, S. and Vasiliou, D. (2020b) Effective corporate income tax rates: Southern and Northern Economies of the European Union, International Journal of Accounting and Financial Reporting, Vol. 10, No. 1, March 2020.

Becker, G. (1968) Crime and Punishment: An Economic Approach, Journal of Political Economy, 76(2) 169-217.

Becker, W., Büchner, H.J. and Sleeking, S. (1987) The Impact of Public Transfer Expenditures on Tax Evasion: An Experimental Approach, Journal of Public Economics, 34 243-252.

Beron, K. J., Tauchen, H. V. and Witte, A. D. (1988) A Structural Equation Model for Tax Compliance and Auditing, NBER Working Papers 2556, National Bureau of Economic Research, Inc.

Bloomquist, K. (2006) A Comparison of Agent-Based Models of Income Tax Evasion, Social Science Computer Review, 24(4) 411-425.

Brooks, N. and Doob, A. H. (1990) Tax evasion: Searching for a theory of compliant behavior, [in:] Securing compliance: Seven case studies", ed. M.L. Friedland, Toronto 1990, 120-164.

Buehn, A. and Schneider, F. (2016) Estimating the Size of the Shadow Economy:Methods, Problems and Open Questions, IZA DP No. 9820.

Caballe, J. and Panades, J. (1997) Tax Evasion and Economic Growth, Public Finance/Finances Publiques, 52 (3-4) 318-340.

Carrillo, P., Pomeranz, D. and Singhal, M. (2014) Dodging the Taxman: Firm Misreporting and Limits to Tax Enforcement, NBER Working Paper No 20624.

Casaburi, L and Troiano, U. (2016) Ghost-house busters: The electoral response to a large anti-tax evasion program, The Quarterly Journal of Economics, 131(1) 273-314.

Cebula, R. (1998) An empirical analysis of the impact of federal budget deficits on longterm nominal interest rate yields, 1973.2-1995.4, using alternative expected inflation measures, Review of Financial Economics, 7(1) 55-64.

Cebula, R. (2001) Impact of income-detection technology and other factors on aggregate income tax evasion: the case of the United States, Banca Nazionale del Lavoro Quarterly Review, Banca Nazionale del Lavoro, 54(219) 401-415. 
Cebula, R.J., Coombs, C., and Yang, B.Z. (2009) The tax reform act of 1986: An assessment in terms of tax compliance behavior in the U.S. , International Economics, 51(2) 247-259.

Cerqueti, R. and Coppier, R. (2011) Economic growth, corruption and tax evasion, Economic Modelling, 28(1-2) 489-500.

Chetty, R., Friedman, J. and Saez, E. (2013) Using Differences in Knowledge across Neighborhoods to Uncover the Impacts of the EITC on Earnings, American Economic Review, 103 2683-2721.

Christie, E. and Holzner, M. (2006) What Explains Tax Evasion? An Empirical Assessment based on European Data, wiiw Working Papers 40, The Vienna Institute for International Economic Studies, wiiw.

Cowell, F.A. (1990) Cheating the government. The economics of tax evasion,Cambridge, MA: MIT Press.

Cuccia, A. (1994) The economics of tax compliance: what do we know and where do we go?, Journal of Accounting Literature, 13 81-116.

DeBacker, J., Heim, BT and Tran, A. (2015) Importing corruption culture from overseas: Evidence from corporate tax evasion in the United States, Journal of Financial Economics, 117 (1) 122-138.

Dell'Anno, R. (2009) Tax evasion, tax morale and policy maker's effectiveness, The Journal of Socio-Economics, 38(6) 988-997.

DeLone, W. and McLean, E. (2003) The DeLone and McLean Model of information systems success: A ten year update, Journal of Management Information Systems, 19(4) 9-30.

Dhami, S. and Al-Nowaihi, A. (2010) Optimal taxation in the presence of tax evasion: Expected utility versus prospect theory, Journal of Economic Behavior \& Organization, 75(2) 313-337.

Domino, M., Giordano, G. and Webinger, M. (2017) An Investigation of the Factors that Impact the Perceived Value of Forensic Accounting Certifications, Journal of Forensic \& Investigative Accounting, 9(1) 1-21.

Elffers, H. (1991) Income Tax Evasion: Theory and Measurement, Deventer: Kluwer Academic Publishers.

Eliezer, O. and B. Emmanuel, B. (2015) Relevance of Forensic Accounting in the Detection and Prevention of Fraud in Nigeria, Historical Research Letter, 23 $17-25$.

Enofe, A.O., Utomwen, O.A. and Danjuma, E.J. (2015) The Role of of Forensic Accounting in Mitigating Financial Crimes, International Journal of Commerce and Management Research, 1(1) 40-47.

Erard, B. and Feinstein, J. S. (1994) The Role of Moral Sentiments and Audit Perceptions in Tax Compliance, Public Finance/Finances Publiques, 49 (Supplement) 70-89.

Feige, E. (1994) The Underground Economy and the Currency Enigma, Public Finance = Finances publiques, 49 119-136.

Feige, E. and Cebula, R. (2011) America's Underground Economy: Measuring the Size, Growth and Determinants of Income Tax Evasion in the U.S, MPRA Paper No. 29672.

Feld, L. P. and Tyran, J. R. (2002) Tax evasion and voting: An experimental analysis, KYKLOS, 55 197-222. 
Fisman, R. and Miguel, E. (2007) Corruption, Norms, and Legal Enforcement: Evidence from Diplomatic Parking Tickets, Journal of Political Economy, 115(6) 1020-1048.

Floropoulos, J., Spathis, C., Halvatzis, D. and Tsipouridou, M. (2010) Measuring the success of the Greek Taxation Information System, International Journal of Information Management, 30 47-56.

Graetz, M.J. and L.L. Wilde, L.L. (1985) The economics of tax compliance: facts and fantasy, National Tax Journal, 38 355-363.

Gupta, R. (2008) Tax evasion and financial repression, Journal of Economics and Business, 60(6) 517-535.

Hashimzade N., Myles, G. and Tran-Nam, B. (2013) Applications of behavioural economics of tax evasion, Journal of Economic Surveys, 27(5) 941-977.

Hite, A. and Roberts, M. L. (1992) An experimental investigation of tax judgment on rate structure in the individual income tax system, Journal of the American Taxation Association, 13, 763.

Hodgson, G. and Jiang, S. (2007) The economics of corruption and the corruption of economics: an institutionalist perspective, Journal of Economic Issues, 41(4) 1043-1061.

Hokamp, S. and Pickhardt, M. (2010) Income Tax Evasion in a Society of Heterogeneous Agents - Evidence from an Agent-based Model, International Economic Journal, 24 541-553.

Hug, S. and Spörri, F. (2011) Referendums, trust, and tax evasion, European Journal of Political Economy, 27(1) 120-131.

Internal Revenue Service, (2007) Reducing the federal tax gap: A report on improving voluntary compliance, August 2, 2007.

Jackson, B. R., and Milliron, V.C. (1986) Tax compliance research: Findings, problems and prospects, Journal of Accounting Literature, 5 125-165.

Joulfaian, D. (2000) Corporate Income Tax Evasion and Managerial Preferences, The Review of Economics and Statistics, 82(4) 698-701.

Khersiat, O.M. (2018) The Role of the Forensic Accountant in the Detection of Tax Fraud in Financial Statements: A Survey Study in the Jordanian Accounting and Auditing Offices and Firms, International Journal of Economics and Finance, 10(5) 145-153.

Kinsey, K.A. (1986) Theories and Models of Tax Cheating, Criminal Justice Abstract, 18 403-425.

Klepper, S. and Nagin, D. (1989a) The Anatomy of Tax Evasion, Journal of Law, Economics, and Organization, 5(1) 1-24.

Klepper, S. and Nagin, D. (1989b) Tax Compliance and Perceptions of the Risks of Detection and Criminal Prosecution", Law \& Society Review, 23(2) 209240.

Kleven, H., Knudsen, M., Kreiner, C., Pedersen, S. and Saez, E. (2011) Unwilling or Unable to Cheat? Evidence from a Randomized Tax Audit Experiment in Denmark, Econometrica, 79 651-692.

Korobow, A., Johnson, C. and Axtell, R. (2007) An Agent-Based Model of Tax Compliance with Social Networks, National Tax Journal, 60(3) 589-610. 
Kumler, T., Verhoogen, E. and Frias, J. (2015) Enlisting Workers in Monitoring Firms: Payroll Tax Compliance in Mexico", Columbia University Academic Commons, Working Paper.

Long, S. and Swingen, J. (1991) Review: Taxpayer Compliance: Setting New Agendas for Research, Law \& Society Review, 25(3) 637-684.

Meldman, R. E. and Sideman, R. J. (2001) Federal Taxation: Practice and Procdure(6th ed.), Chicago: CCH Incorporated.

Musgrave, R. (1987) Short of Euphoria, Journal of Economic Perspectives, 1 (1) 5971.

Myles, G. (1995) Public Economics, CambridgeUniversity Press.

Naritomi, J. (2015) Consumers as Tax Auditors, LSE Working Paper.

Ott, A. and Vegari, S. (2003) Tax reform: Chasing the elusive dream, Atlantic Economic Journal, 31(3) 266-282.

Pappa, E., Sajedi, R. and Vella, E. (2015) Fiscal consolidation with tax evasion and corruption, Journal of International Economics, 96(1) 56-75.

Pellegrini L. (2011) Corruption, Development and the Environment, Springer Editions.

Pestieau, P., Possen, U. and Slutsky, S. (1994) Optimal Differential Taxes and Penalties, Public Finance/Finances Publiques, 49 (Supplement) 15-27.

Pickhardt, M. and Prinz, A. (2014) Behavioral dynamics of tax evasion - A survey, Journal of Economic Psychology, 40 1-19.

Pommerehne, W.W. and Weck-Hannemann, H. (1996) Tax rates, tax administration and income tax evasion in Switzerland, Public Choice, 88 161-170.

Pomeranz, D. (2015) No Taxation without Information: Deterrence and SelfEnforcement in the Value Added Tax, American Economic Review, 105 2539-2569.

Richardson G. (2006) Determinants of tax evasion: A cross-country investigation, Journal of International Accounting, Auditing and Taxation, 15 150-169.

Richardson, M. and Sawyer, A. (2001) A taxonomy of tax compliance literature: Further findings, problems and prospects, Australian Tax Forum, 16(2) 137320.

Riahi-Belkaoiu, A. (2004) Relationship between tax compliance internationally and selected determinants of tax morale, Journal of International Accounting, Auditing and Taxation, 13 135-143.

Saez, E. (2010) Do Taxpayers Bunch at Kink Points?, American Economic Journal: Economic Policy, 2 180-212.

Sandmo, A. (2004) The Theory of Tax Evasion: A Retrospective View, National Tax Journal, 58(4) 643-663.

Sanyal, A., Gang, I. N. and Goswami, O. (2000) Corruption, Tax Evasion and the Laffer Curve, Public Choice, 105(1-2) 61-78.

Sarker, T. (2003) Improving Tax Compliance in Developing Countries via SelfAssessment Systems - What Could Bangladesh Learn from Japan?, AsiaPacific Tax Bulleting, 9(6) 170-176.

Schneider, F. (2002) The Size and Development of the Shadow Economies of 22 Transition and 21 OECD Countries, IZA Discussion Paper No. 514.

Schneider, F., Raczkowski, K. and Mróz, B. (2015) Shadow economy and tax evasion in the EU, Journal of Money Laundering Control, 18(1) 34-51. 
European Journal of Accounting, Auditing and Finance Research

Vol.8, No.2, pp.59-80, February 2020

Published by ECRTD-UK

Print ISSN: 2053-4086(Print), Online ISSN: 2053-4094(Online)

Schnellenbach, J. (2006) Tax Morale and the Taming of Leviathan, Constitutional Political Economy, 17(2) 117-132.

Seddon, P. (1997) A respecification and extension of the DeLone and McLean model of IS success, Information Systems Research, 8(3) 240-253.

Slemrod, J. (1992) Did the Tax Reform Act of 1986 Simplify Tax Matters?, Journal of Economic Perspectives, 6(1) 45-57.

Slemrod, J., Blumenthal, M. and Christian, C. (2001) Taxpayer response to an increased probability of audit: evidence from a controlled experiment in Minnesota, Journal of Public Economics, 79(3) 455-483.

Snow, A. and Warren, R. (2005) Ambiguity about Audit Probability, Tax Compliance and Taxpayer Welfare, Economic Inquiry, 43 865-871.

Song, Y.-D. and Yarbrough, T. (1978) Tax Ethics and Taxpayer Attitudes: A Survey, Public Administration Review, 38(5) 442-452

Spicer, M. W. (1974) A behavioral model of income tax evasion, Dissertation, Ohio State University.

Spicer, M. W. and Lundstedt, S. B. (1976) Understanding Tax Evasion, Public Finance = Finances publiques, 31(2) 295-305.

Strümpel, B. (1969), The contribution of survey research to public finance, in Peacock, A.T. (Ed.), Quantitative Analysis in Public Finance, Praeger Publishers, New York, NY, pp. 14-32.

Tan, L. and Sawyer, A. J. (2003) A synopsis of taxpayer compliance studies: verview vis-a-vis New Zealand, New Zealand journal of taxation and law policy, 9(4) 431-454.

Tanzi, V. (2000) Policies, Institutions and the Dark Side of Economics, Cheltenham, England: Edward Elgar.

Torgler, B. (2001) What Do We Know about Tax Morale and Tax Compliance?, International Review of Economics and Business (RISEC), 48 395-419.

Torgler, B. (2003a) Tax morale and institutions, Working Paper No. 2003-09. Basel, Switzerland: Center for Research in Economics, Management and the Arts.

Torgler, B. (2003b) Tax Morale, Rule-Governed Behaviour and Trust, Constitutional Political Economy, 14(2) 119-140.

Torgler, B. (2006) The importance of faith: Tax morale and religiosity, Journal of Economic Behavior \& Organization, 61(1) 81-109.

Torgler, B. and Murphy, K. (2004) Tax Morale in Australia: What Shapes it and Has it Changed over Time?, CREMA Working Paper Series 2004-04, Center for Research in Economics, Management.

Torgler, B., Schaltegger, C. A. and Schaffner, M. (2003) Is forgiveness divine? Acrossculture comparison of tax amnesties, Swiss Journal of Economics and Statistics, 139 375-396.

Wallschutzky, I. G. (1984) Possible causes of tax evasion, Journal of Economic Psychology, 5(4) 371-384.

Witte, A. D. and Woodbury, D. F. (1985) The effect of tax laws and tax administration on tax compliance: The case of the U.S. individual income tax, National Tax Journal, 38 1-13.

Yang, D. (2008a) Can Enforcement Backfire? Crime Displacement in the Context of Customs Reform in the Philippines, Review of Economics and Statistics, 90 $1-14$. 
Yang, D. (2008b) Integrity for Hire: An Analysis of a Widespread Customs Reform, Journal of Law and Economics, 51 25-58.

Yitzhaki, S. (1974) Income tax evasion: A theoretical analysis, Journal of Public Economics, 3(2) 201-202.

Zaklan, G., Lima, F. And Westerhoff, F. (2008) Controlling tax evasion fluctuations, Physica A: Statistical Mechanics and its Applications, 38(23) 5857-5861.

Zaklan, G., Westerhoff, F. and Stauffer, D. (2009) Analysing tax evasion dynamics via the Ising model, Journal of Economic Interaction and Coordination, 4(1) 115 . 